\title{
Fiscal Decentralization and Economic Growth in Nigeria: New Evidences
}

\author{
Johnson Akpan Atan, Godwin Essang Esu \\ Department of Economics, Faculty of Social Sciences, University of Uyo, Uyo, Nigeria \\ Email address: \\ essangabasi@yahoo.com (G. E. Esu)

\section{To cite this article:} \\ Johnson Akpan Atan, Godwin Essang Esu. Fiscal Decentralization and Economic Growth in Nigeria: New Evidences. Journal of Business \\ and Economic Development. Vol. 6, No. 2, 2021, pp. 82-96. doi: 10.11648/j.jbed.20210602.14
}

Received: April 20, 2021; Accepted: May 10, 2021; Published: May 21, 2021

\begin{abstract}
The debate regarding the role of fiscal decentralization in promoting economic growth and by extension, improving the wellbeing of the people, has been at the front burner in macroeconomic policy discuss. Studies have attempted to establish the direct interaction for most countries and regions, but not many conclusions have converged, hence necessitating this study. This study, therefore, re-examined the effect of decentralization on economic growth in Nigeria. Using fiscal decentralization data, (which included expenditures for national, subnational and local government) and other control variables, sourced from mainly secondary sources (World Development Indicators [WDI] and Central Bank of Nigeria's [CBN] Statistical Bulletin various years) and employing basic OLS technique and Error Correction Mechanism (ECM), the results showed, amongst other issues, that fiscal decentralisation may not directly impact on economic growth, but the effects can be transmitted through efficient economic management process, which may be a product of effectively-managed fiscal decentralization processes. The study, therefore, recommended, amongst other things, that efficient systems should be promoted in the decentralization process to enhance economic growth. Viable human capital/infrastructure base should be built to drive as well as enhance productive fiscal decentralization, through strategic policies finetuning, and finally, check inflation and corruption, amongst other ills, if growth must be actualized and sustained.
\end{abstract}

Keywords: Fiscal Decentralisation, Economic Growth, ECM

\section{Background to the Study}

\section{Introduction}

Economic history, political conditions and regional differentials constitute a major issue in fiscal relations between various tiers of government. The preoccupation of every nation is to improve on the efficiency in the delivery of public goods. In a federation, the central question revolves around which level of government is better equipped to undertake provision of a particular public good. Fiscal decentralization is the devolution of powers on fiscal matters from the central government to the sub-national governments. It entails increasing the relative autonomy for expenditure and revenue to the other federating units. These decentralisation process have been increasingly perceived as critical part of a reform process targeted at reducing inefficiencies in the public sector and boosting economic growth $([7,13,64])$.
Fiscal decentralization has been adopted rapidly as a policy measure in the last three decades ([1]). During the same period, it has also found a spot on the World Bank's agenda as one of the major governance reforms ([96, 18]). There has also been an increasing interest amongst researchers on the prospects of fiscal decentralization in facilitating economic growth, but overall, the literature on fiscal decentralisation, especially in the context of development, is still in its early stages ([75, 9]).

Also, there are two fundamental arguments in favour of fiscal decentralization: First, Population mobility across localities ensure a better matching of preferences between local governments and local communities, which makes the devolution of resources to regional and local governments apt in getting closer to the need of the people ([88]). Second, the advantage of being in close proximity to the final consumers enables local governments to have information advantage and achieve a more efficient delivery of public goods [42]. 
Thus, in recent times, the traditional theories advocating for devolution of resources and power to the lower levels have been enhanced, though challenged in some quarters and the weaknesses of fiscal decentralization highlighted. However, some studies have still shown a differential impact of decentralization across the developed and developing world. ([20]).

Fiscal decentralization could be seen as the process of devolving fiscal responsibility to lower levels of government in accordance with local needs and preferences. In general, fiscal decentralization entails that the authority of tax collection or expenditure is transferred from superior offices to subordinate offices (Choi Jung, 2001) for the purpose of producing appropriate public-services for improving the public welfare of residents.

The close competition between revenue and expenditure assignment at sub-national levels benefits allocative efficiency, resulting in economic growth. Fiscal decentralization is often seen as part of a reform package to improve efficiency in the public sector, to increase competition among subnational governments in delivering public services, and to stimulate economic growth ([13]). In summary, the main issues of concern regarding fiscal decentralization and economic growth are tax jurisdictions, expenditure responsibilities and resource allocation. The Nigerian case is not in isolation as far as those issues are concerned. Constitutionally, Nigeria assigns more and juicy expenditure responsibilities to the central (federal) government.

As enshrined in the 1999 constitution (as amended), expenditure responsibilities on defence, foreign affairs, international trade (including export marking), currency, banking, borrowing, exchange control, use of water resources, shipping and federal trunk roads. Others include expenditure on elections, aviation, railways, postal services, police and other security services. The centre also controls the regulation of labour, interstate commerce, telecommunications, immigration, mines and minerals, nuclear energy, citizenship and naturalization rights and social security. Others are insurance, national statistics system, guidelines and basis for minimum education, business registration and price control.

Despite such concentration of responsibility at the centre, the federal government still shares major assigned expenditure with the state government. These include expenditure on health, social welfare, education (post primary/tertiary), culture, antiquities, statistics, stamp duties, commerce, industry, electricity (general, transmission, distribution), and research surveys, aside residual power or responsibility that the state handles alone. For the local government, the responsibilities are that of economic planning and development, health services, land use, control and regulation of advisements, pets, small business, markets, public conveniences, social welfare, sewage and refuse disposal, registration of births, deaths and marriages. Others include primary, adult and vocational education, development of agriculture and natural resources.

Since, at least theoretically, a federal system should be characterized by a diffused decentralization, the problem is therefore revealed in this big question: with the skewed distribution of the expenditure responsibilities, can fiscal decentralisation directly fuel economic growth in the case of Nigeria? Our pursuit in this paper, therefore, is to empirically examine the effectiveness of fiscal decentralization vis-à-vis its impact on the growth of the Nigerian economy. Specifically, it is to empirically establish the direct interaction or otherwise between fiscal decentralisation and economic growth for Nigeria. In view of this, the rest of the paper is presented in sections 2 to 6 . Stylized facts and conceptual issues regarding fiscal decentralisation is presented in section 2 . In section 3 , relevant literatures are reviewed and evaluated, while theoretical issues and models of the study are discussed in section 4. Results and analysis of findings are presented in section 5, while the study is concluded in section 6 , with some policy implications of the findings highlighted.

\section{Fiscal Decentralization: Some Stylized Facts}

Fiscal decentralization is predicated on four major fiscal operation channels viz: revenue assignment, expenditure assignment, intergovernmental transfers/grant designs and borrowing. In Nigeria, the bulk of the revenue that accrues to the subnational governments comes from the centre. This is because the critical mass of revenue-generating structures are being assigned to the national government, with the subnational government being left with little, hence the fiscal dependence on the centre. Figure 1 shows the behavour of internally generated revenue of federal, state and local governments in Nigeria.
FGRR

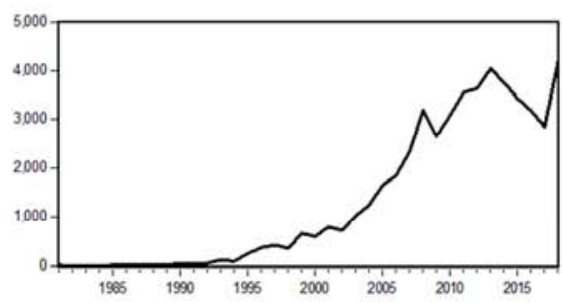

SGR

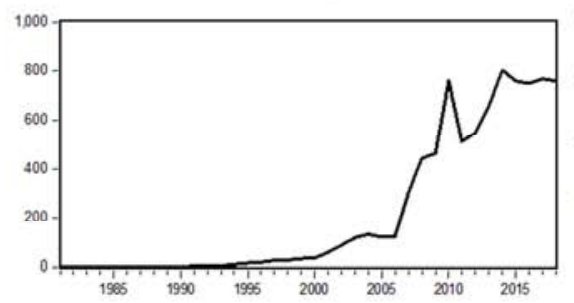

LGIR

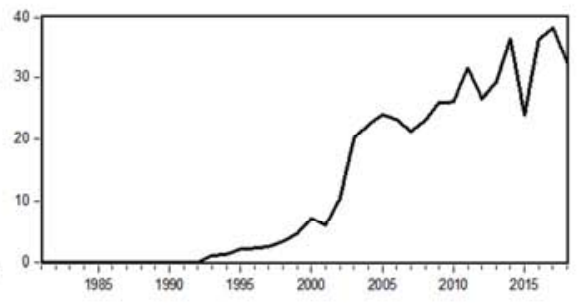

Figure 1. Federal, State and Local Governments Internally Generated Revenue. 
Closer observation of Figure 1 shows that internally generated revenue (IGR) for the national government has been relatively stable compared to that of state and local governments. The explanation to such disparities is the dimension upon which responsibility assignment tilts. The revenue responsibility assignment leaves much to be desired as far as fiscal decentralisation is concerned. However, within the period under review, revenue at different levels of government have shown considerable progress. For instance, in 1993, federal government retained revenue stood at $\$ 126.0712$ billion, but rose to 1023.241 billion in 2003, representing an increase of $\$ 897.1698$ billion (which is about $78.06 \%$ increase) over the period. Expenditures over the period also increased from \#191.2289 billion in 1993 to 1225.988 billion in 2003, representing a rise to the tune of $1,034.711$ billion, representing about $73.01 \%$ increase in federal government expenditure within the period. The improvement in revenue within the period notwithstanding, the figures show that the federal government had operated deficit budgets over the period.

A similar analysis of the trend in a more recent periods have not shown anything of much difference. For example, between 1994 as and 2018, revenue rose from 1253.6 billion to 4185.644 billion respectively. This shows an increase in revenue within the period to the tune of \#2,932.044 billion, representing a 53.90\% rise in federal government retained revenue. On the other hand, expenditure rose from 1426.2 billion in 1994 to 7813.741 billion in 2018 , representing a $69.12 \%$ rise (or $\$ 6,387.541$ billion increase). Figure 2 shows federal government total expenditure trend from 1981 to 2018.

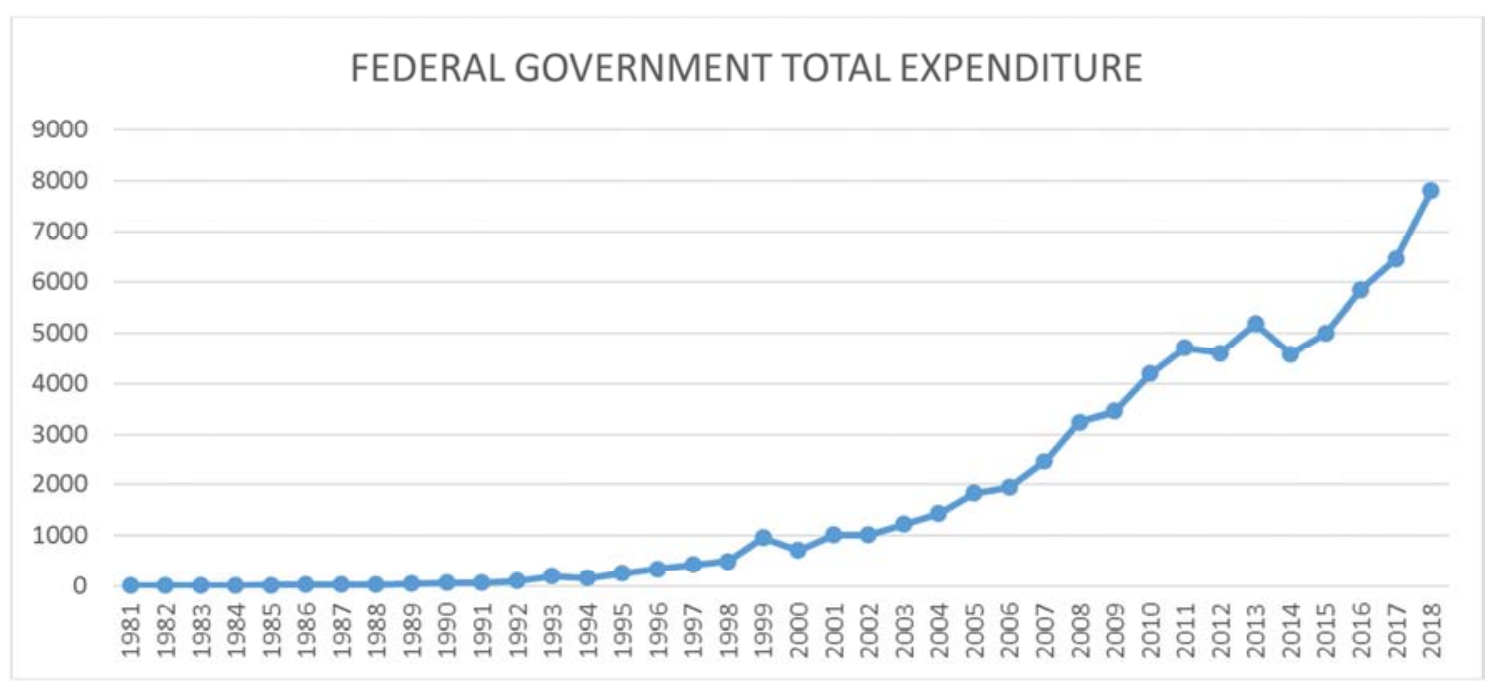

Figure 2. Federal Government Total Expenditure.

The revenue and expenditure behaviour in the state and local levels of decentralisation have not differed significantly from the federal characteristics that we have seen so far. This may not be unconnected to the imbalances in the decentralisation process between the centre and other federating units. The revenue and expenditure responsibility assignment seems not to have been holistically decentralized, as the subnational units seem to be heavily dependent on the centre. For instance, in response to the improvement in federal revenue in 1993, state revenue rose from \$5.7262 billion in 1993 to 118.7535 billion in 2003. This represents $90.80 \%$ increase (or 113.0273 billion increase) in the states' IGR within the period under review. However, expenditure escalated from 44.1809 billion in 1993 to $\$ 921.1597$ billion in 2003 representing an increase in expenditure to the tune of \#876.9788 billion (or $90.85 \%$ increase) within the period.

There had been no significant difference in the trend subsequently. Between 1994 and 2018, states revenue reflected a $72.84 \%$ increase. The states' IGR rose from \# 118.7535 billion in 1994 to 755.7 billion in 2018 , a \#636.9465 billion increase over the period. In the same vein, state government expenditure rose from $\$ 1,125.057$ billion in 1994 to $44,459.601$ billion in 2018 . This reflects a $59.71 \%$ rise in states expenditure stock - about $\$ 3,334.544$ billion increase in expenditure at that level over the period. Theoretically, these expenditure shots are expected to boost aggregate demand and engender growth in all sectors of the economy and reduce unemployment or at least stabilize the cycle, which of course should translate to improved standard of living and general wellbeing of the people. Figure 3 shows the states government expenditure trend from 1981 to 2018.

Local governments' revenue and expenditure pattern have reflected a similar trend as the centre and state governments over the period under review. Local government revenue rose from ? 1.0356 billion in 1993 to 20.1755 in 2003, representing about $90.23 \%$ surge (or ? 19.1399 billion increase) in local government IGR, but their expenditure within that period grew from ? 19.4753 billion in 1993 to 3361.7132 billion in 2003. This represented an increase in expenditure to the tone of about 342.2379 billion (or $89.78 \%$ rise) within the period. The trend was not different in the second period. Revenue that accrued to the local governments rose from ?22.40775 billion in 1994 to ? 32.5 billion in 2018 . 


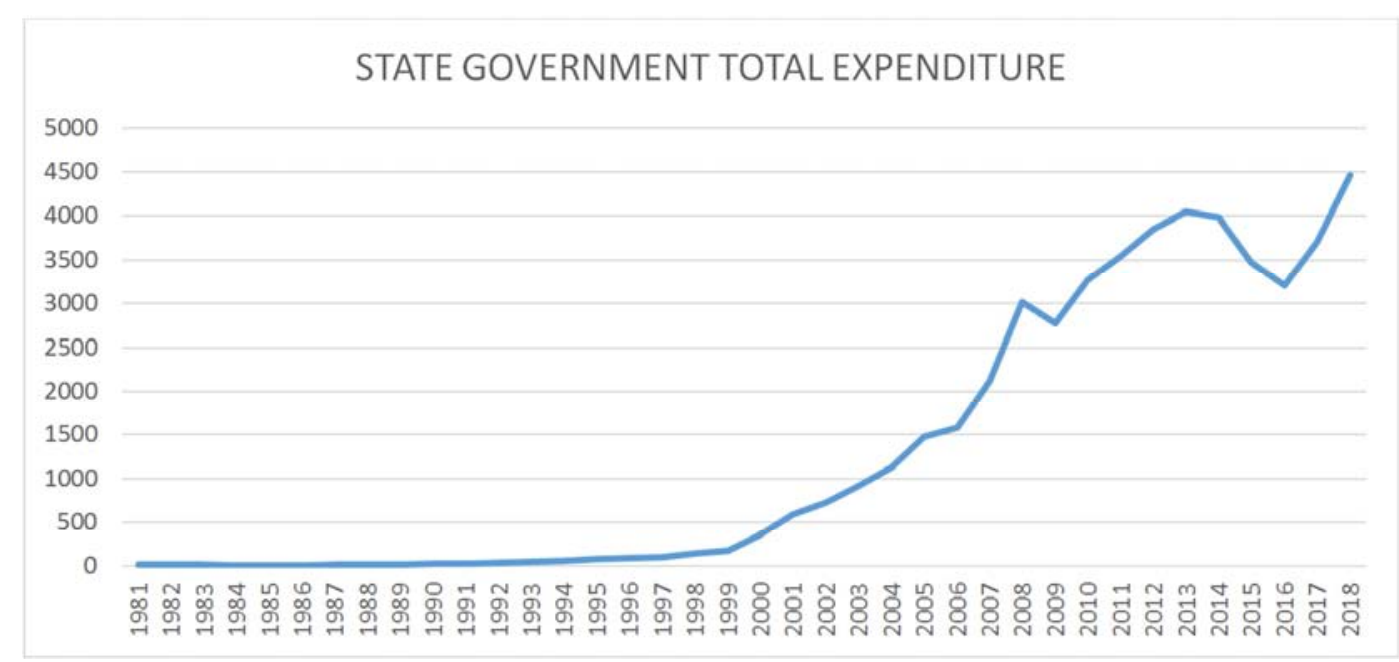

Figure 3. State Government Total Expenditure.

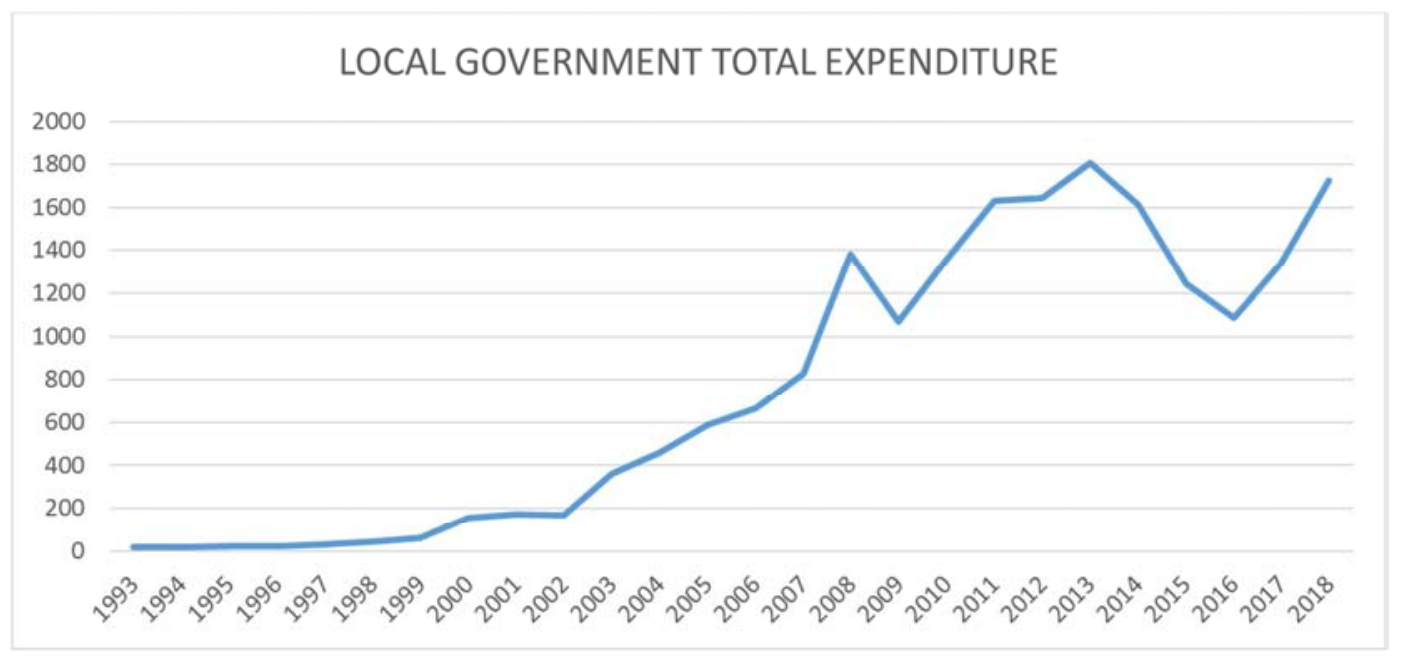

Figure 4. Local Government Total Expenditure.

This showed a $18.38 \%$ rise in their revenue covering an increase of about 10.09225 billion over the period. On the other hand, expenditure rose within the same period from ? 461.0506 billion to ? 1724.967 billion, representing about $57.82 \%$ rise in their expenditure, which covered about
? 1,263.9164 billion increase in expenditure. This underlines one recurring decimal and that is persistent deficit financing operations at all levels of fiscal decentralisation in Nigeria. Figure 4 shows expenditure structure of the local governments over the period under review.

\section{GDP GROWTH RATE: 1981 - 2018}

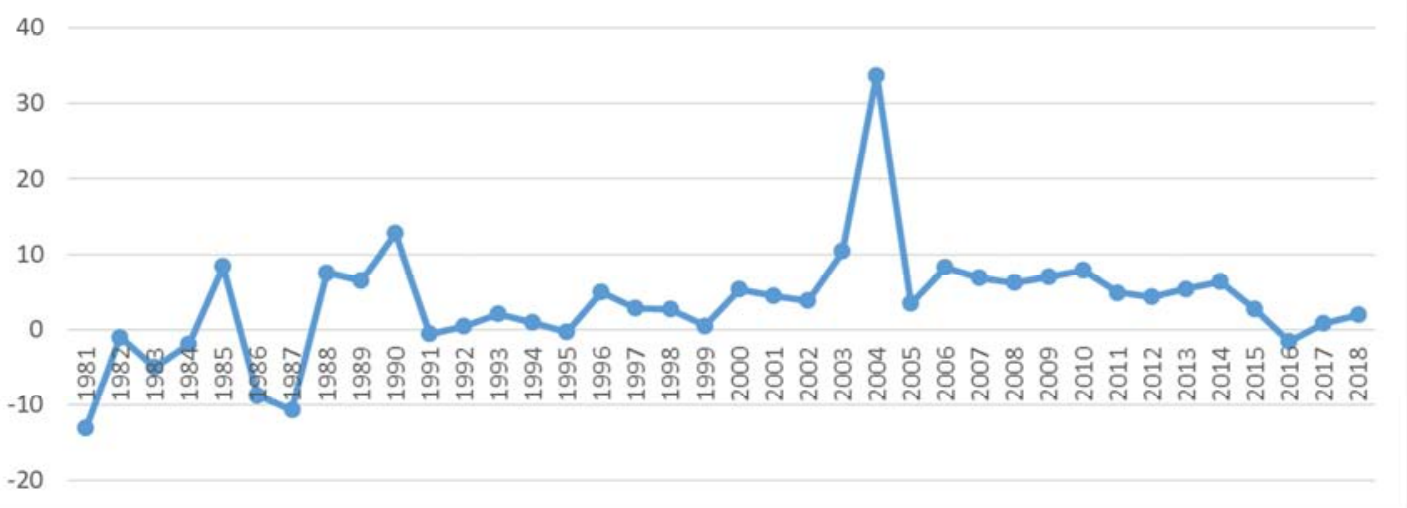

Figure 5. GDP Growth Rate in Nigeria 1981 - 2018. 
A closer look at figure 5 indicates that the rate of volatility in the GDP growth rate corroborates our foregoing argument of the fact the decentralisation or devolution process, in the case of Nigeria, is tilted. Except for the period between 2002 and 2005 that saw a reasonably stable growth rate in GDP, which may be attributed, largely to debt forgiveness by Nigeria's creditors, the rest of the periods within our consideration had been largely volatile and retarding in some cases: 1981 to 1987 for instance. Inflation in those periods had also been highly volatile and overwhelmingly high in some of those years, example was 1981, 1983, 1984, 1988,
1989, 1992, 1993, 1994 and 1995 respectively (see Figure 6).

The results of these instabilities seem to be retarded economic growth, and steady rise in unemployment. As reflected in Figure 7, unemployment has been steadily on the rise generally since 1992. The explanation to this could be that despite the attempt to create more states and local governments with the intention of bring economic progress closer to the people through devolution of fiscal powers and responsibility amid political powers, the different levels of decentralisation have recorded much benefit, may be due to unwholesome practices and tilted implementations of the policies and processes.

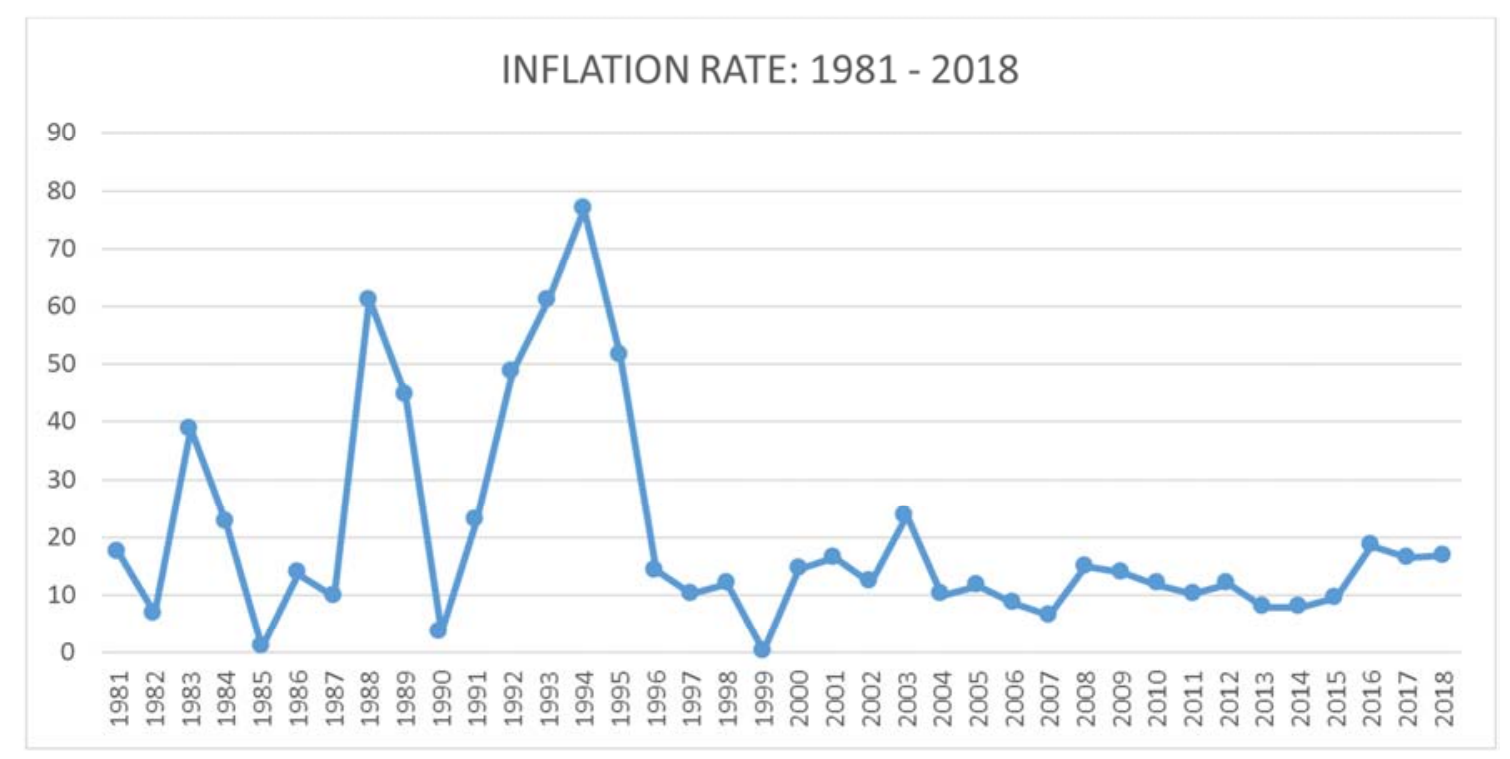

Figure 6. Inflation Rate in Nigeria: $1981-2018$.

Thus, a rising deficit financing, retarding GDP growth rate, rising rate of inflation and rising unemployment rate, can only reflect non-growth consequences. The outcome this analysis has thrown up seems to corroborate the findings by some authors, that fiscal decentralisation may not have direct growth impact on the economy.

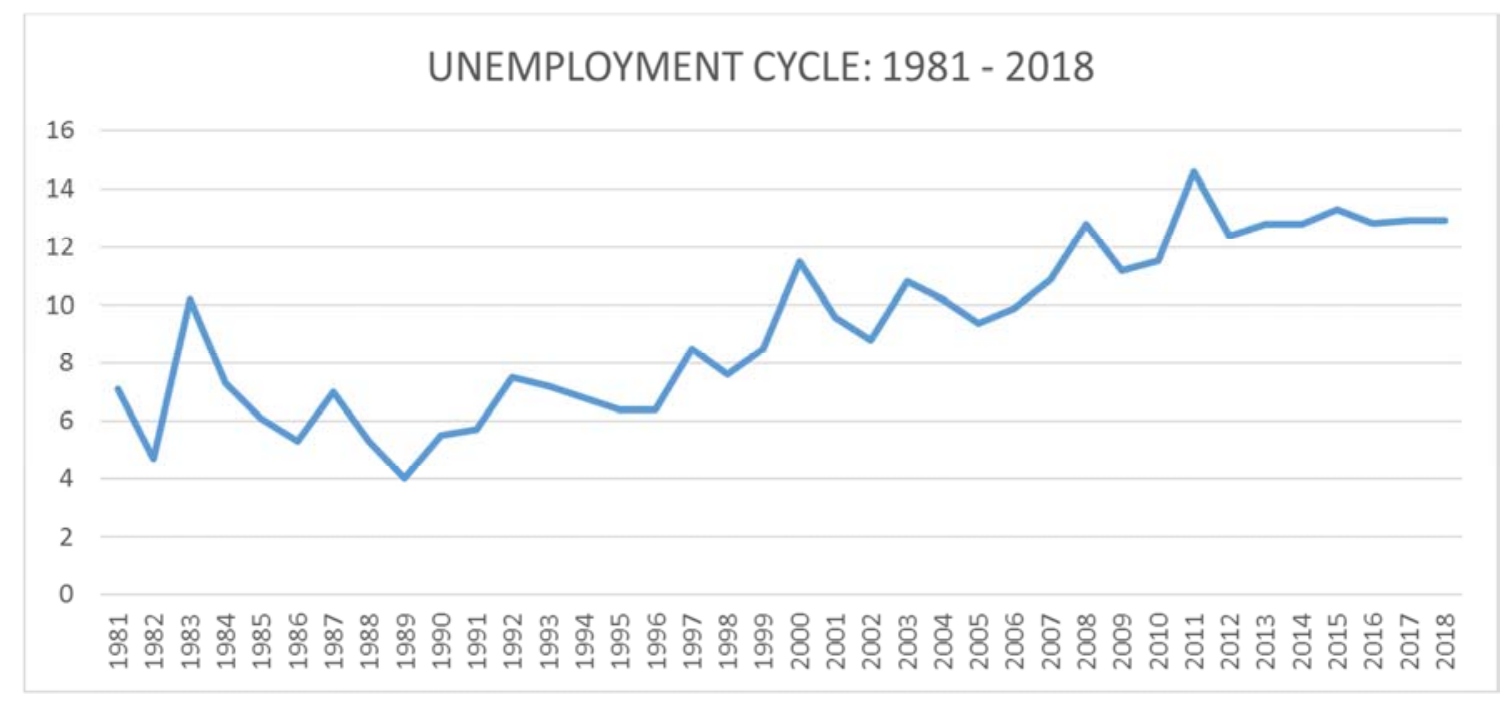

Figure 7. Unemployment Level in Nigeria 1981 - 2018.

While some have hold this to be true for OECD countries, e.g. [51]; others argue for its injurious impact on economic growth, especially in developing economies, e.g. $[6,10,21]$ and [70]. However, Prud'homme had argued that economic growth implication of fiscal decentralisation may home for developed economies [68]. These positions further drive our 
interest in investigating the role of fiscal decentralization in the growth of the Nigerian economy, and to find out why if the reverse hold for Nigeria as found by other scholars for countries and regions around the world.

\section{Review of Relevant Literature}

Martinez-Vazquez and McNab have argued that traditionally, both theory and practice of fiscal decentralization has given peripheral attention to its capacity to foster economic growth, except in recent times where normative discussions of fiscal decentralization added economic growth to the traditional list of public finance objectives of efficiency in the allocation of resources, horizontal fiscal imbalances, and economic stabilization [47]. This they attributed to the lack of theoretical underpinnings, required to give strength to empirical findings. They concluded that fiscal decentralization may indeed have a direct impact on economic growth but the theoretical grounds for this relationship remain largely undeveloped. The absence of an adequate theoretical framework has undermined the validity of the empirical work on this subject. However, some scholars have concluded that, the traditional argument for fiscal decentralization is that it may provide greater economic efficiency in the allocation of resources in the public sector (see for example, [59, 15]).

The noticeable feature of the recent state of the fiscal decentralization literature is the scantiness of empirical evidence regarding the effects of decentralization, not only on economic growth, but also on the traditional objectives of economic efficiency, income distribution, and macroeconomic stability ([48]). However, it has been documented in the literature, that the impact of fiscal decentralization in fostering economic growth, is deepened in the developed economies than it is in the developing economies ([7]). This correlation between economic development and the depth of decentralization may also be due to the fact that many developing countries inherited highly centralized systems at the time of their independence from their colonial powers (see [48]).

While sizeable studies in recent times have attempted to quantify the role of government expenditures on economic growth, the question of what impact decentralized government expenditures exert on economic growth remains largely unaddressed. Some scholars found that an increasing share of central government consumption in GDP is negatively associated with growth in per capita income ([6] and [10]). In an earlier study, [69] found a positive relationship between central government consumption in GDP and growth in per capita income. Devarajan, Swaroop, and Zou examined the impact of the composition of public expenditures on economic growth and found that while an increase in the share of current central government expenditure has a positive and statistically significant effect on growth, the capital component of public expenditure has a negative impact on per capita growth [21].

Prud'homme, in further establishing the disagreement amongst scholars on the commonly-held position of a positive relationship between fiscal decentralization and economic growth, opined that fiscal decentralization is primarily fit for developed countries and faces myriad challenges in the developing economies [68]. When the economies of scale are compromised, lower tiers of government may not be large enough to provide public goods effectively. Davoodi and Zou deviate from the basic neo-classical production function and develop a model showing that growth is not only affected by total public spending but also the relative expenditure shares of different levels of government [19]. In a panel study of 46 countries, they found a significantly negative effect of fiscal decentralization in developing countries and an insignificant effect for their developed counterparts. This opened up for studies. Martinez-Vazquez and $\mathrm{McNab}$ explained decentralization to be a superior good [49], while Rodden viewed fiscal decentralization as harmful for developing countries [70].

Rodriguez-Pose and Gill, in furtherance of the argument, held that in developing countries (e.g., Brazil) subnational governments indulging in fiscal profligacy accumulated significant deficits and resorted to the central government to bail them out [72]. Treisman believed that such an increasing trend in sub-national government deficits interferes with the budget of central government and inflation targets [87]. Illner, however, argued from the perspective of corruption [39]. $\mathrm{He}$ found that monitoring of public bureaucrats is difficult and accountability hard to enforce in low-income countries which increases the likelihood of corruption and opportunistic behaviour. In a related development, Thiessen found an inverted U-shaped non-linear relation between fiscal decentralization and growth, and argues that negative effects of decentralization will take over beyond an optimum level [84].

Zhang and Zou found a negative relation between decentralization and economic growth for China in the post reform era [99]. Baskaran and Feld, in a panel study of 23 OECD countries from 1975 to 2001, found a non-robust negative decentralization effect [11]. Rodriguez-Pose and Ezcurra also found a negative and significant growth effect of decentralization for a sample of OECD countries from 1990 to 2005 [74]. More recently, Gemmell, Kneller and Sanz investigate a panel data set of 23 OECD countries from 19722005 and find that spending decentralization is associated with negative growth whereas the effect turns positive for revenue decentralization [34]. Szarowska found a negative revenue decentralization effect on output for the European Union from 1995 to 2012 [82].

Agarwal examined the impact of fiscal decentralization on state level economic growth in India, focusing on a nonuniform impact of fiscal decentralization within that economy [4]. Developing a social development index (SDI) to characterize 15 Indian state into developed and underdeveloped, based on their education and health status, and employing an analytical model, he identified the specific channels through which fiscal decentralization impacts economic growth. Is results suggest that both expenditure and revenue decentralization have a larger negative impact on growth in underdeveloped states. For Nigeria, Aigbokhan, Udah and Ndiyo, and recently, Udoh, Afangideh and Udeaja 
have equally found a negative relationship between fiscal decentralization and economic growth, as well as efficiency in service provision [2, 88] and [89].

However, there are arguments and conclusions in favour of positive fiscal decentralization-economic growth interactions. Traditionally, it all began with [86] and then [59]. They argued that people in different localities have different demand schedules and mobility of population across territories ensures a correct match between the preferences of local communities and local provision of public goods. To Klugman, Since local bodies are located closer to the people, they have an information advantage and are better positioned to align public goods delivery according to the regional variation in demand [41]. Martinez-Vazquez and McNab believe that Such a diversification of government output can save valuable resources [49]. Other scholars held that competition occasioned by decentralization could check tendencies for hurting tax system, encourage optimal systems of taxation and efficient delivery of public goods. Decentralization can also enhance markets as a consequence of competition among subnational governments ([91, 53]). Decentralization can affect economic growth by improving macroeconomic stability ([32]), which has been increasingly viewed as the most important policy goal in a host of developed and developing countries.

Other studies that have strengthened the case for fiscal decentralization are that of Zhang and Zou for a panel of 16 Indian states from 1970-1994 found a significantly positive impact of decentralization on state growth rates [99]. Akai and Sakata found a positive and significant impact of fiscal decentralization on state GDP in a panel of US states from 1992-1996 [3]. Piriou-Sall also found this positive correlation for US [67]. Yilmaz distinguishes between federal and unitary states in his study comprising of 46 countries for the period 1971-1990 and found a positively significant effect for the unitary states [97]. Ilmi studied a panel of 51 developed and developing countries for the period 1997-2001 and found a significantly positive impact of decentralization in his short run analysis [38].

In summary, recent studies have reiterated three major concerns in the economics literature from the perspective of fiscal decentralization. The first refers to the issue of adjustments in governance. It concerns how governance is affected by devolving revenue and expenditure powers to regional institutions (i.e., state, municipal, and local governments). Works in this direction include [5, 20, 4, 43]. Country-specific studies include [56] analyzing India; [79] for China; and [8] in Uganda. The second concern has to do with how fiscal decentralization affects economic growth, and by extension, economic stability (the major focus of this study). The major contributions in this regard included the works of $[19,71,49,50,85,58,74,34,14]$. Country-based studies included [96] on China, [95] for the United States, and [77] for Iran; [65] and [64] for Nigeria.

Lastly, the ways in which fiscal decentralization affects poverty, inequality, and wealth redistribution has also received significant consideration. The main contributions in these areas were that of $[16,78,35,76]$. For country-specific studies, a sample of contributions included [31] focusing on Uganda, [80] on China, and [98] on Indonesia.

Specific studies concerning fiscal decentralization in the Americas include [22], exploring the politics of fiscal authority and focusing on the centralization of taxation in Latin America during the twentieth century; [29], focusing on Argentina, Bolivia, Brazil, Mexico, Peru, and a sample of Asian countries and highlighting the divergent historical evolution of the decentralization process in these nations; and [17] analyzing the impact of decentralization on growth, inflation and inequality in twelve American nations.

In terms of relevance to this work, how fiscal decentralization affects economic growth, [64], analyzed the relationship between decentralization and the extent of rent extraction by private parties, with findings suggesting a strong negative relationship between expenditure decentralization and corruption; [70], highlighting the importance of self-autonomy in subnational governments and found that long-term balanced budgets among subnational governments may like result when (1) the central government imposes borrowing restrictions or (2) when subnational governments have both wide-ranging taxing and borrowing autonomy. [28], focusing on Bolivia, examined whether decentralization increases the responsiveness of public investment to local needs; [92], showed that in Argentina there is a significant positive relationship between local government performance and citizen system support.

Weingast in the same vein, analyzed second generation fiscal federalism and underlined the importance of fiscal incentives for producing local economic prosperity [91], while [55] showed that citizen involvement increases in decentralized governments, and this has a number of positive effects on democracy: this includes strengthening issue knowledge, civic skills, and public engagement, and hence it magnifying the basic liberties of constituents in decentralized regions. [27], with special concentration on Colombia and found that administrative and fiscal decentralization improve perceptions of accountability among citizens, but [42], showed that political and fiscal decentralization affect democratic quality and citizen participation in politics (a case for the role of strong institutions).

Islam, with focus on Bangladesh, showed that strong local governments deepen the democratic process by ensuring participatory development [40]. One fact stands out from the review so far, and that is the fact that there is paucity of literature in this area of interest as it concerns Sub-Saharan Africa, and very insignificant as regards country-specific in Nigeria, except for the works of $[25,26,2,23]$, that focused more on the traditional issues of fiscal federalism, and recently $[65,88,89,64]$, that focused on fiscal decentralization and economic Growth. Their findings however, showed a negative effect of fiscal decentralization on human resource development, and the promotion of inefficiency in the provision of public good. This obvious gap and our quest to probe for new evidences, form part of our motivation to carrying on this study to examine what the 
case is in terms of fiscal-decentralization-growth nexus for Nigeria, at the time where the country's economy seems to be very volatile.

\section{Methodology}

Though the theoretical base for fiscal decentralization dates back to the $17^{\text {th }}$ and $18^{\text {th }}$ centuries $([36,28])$, modern theorists $([12,60])$ have not established a direct relationship between fiscal decentralization and economic growth. The empirical work on the potential impact of fiscal decentralization on economic growth has offered thus far little detailed discussion of why we should expect this relationship to exist. Oates, however, attempted establishing indirect theoretical link by arguing that intuitively, the static proposition that fiscal decentralization enhances economic efficiency should have a parallel in the dynamic setting of economic growth [60].

Thus, expenditures for infrastructure and the social sector that respond to regional or local differences are likely to be more effective in enhancing economic growth and development than central policies which may ignore those differences. However, Oates seems to be not very explicit about what this means. The basic question is why, for example, N1 million spent on roads or education at the subnational level should be more growth-enhancing than the same amount of money spent at the national level. The direct effect, pointed out by Oates, indicated that if subnational governments have an advantage in making public expenditures more efficient by better satisfying the needs and preferences of local taxpayers (based on better knowledge of these preferences), then this "static" advantage can also be present in a "dynamic" sense by having subnational government expenditures be more growth enhancing.

Lending a voice, [12] have argued that in appreciating the necessity for decentralization, two parameters should be considered: (1) efficiency values- "maximization" of social welfare taking into account inability of the public sector to contain the same price signals as the private sector, to regulate supply and demand; (2) governance values including responsiveness and accountability, diversity, and political participation. This further strengthens the position on theoretical linkage of fiscal decentralization-economic growth nexus. Is it based on this premise that the motive for this research work is being driven.

Typically, Zou employ a model based on [10]'s endogenous growth, where the production function for the economy has multiple inputs including private capital and multiple public spending by the three levels of government. While [19] use the Levine-Renelt conditioning variables (investment, population growth, human capital) to test the fragility of the estimate for fiscal decentralization, they did not control for the impact of the external sector ([47]).

For this study, therefore, we utilized the Endogenous Growth Theory. The application of endogenous growth theory became popular from the works of Moosa (2002), [21]. However, amongst the pioneer contributions in its original perspective was the work of [10] and later, [18]. Barro made use of the endogenous growth model to find a linkage between public revenues, spending and economic growth. This foundation informed our attempt to establish the fiscaldecentralisation-economic-growth linkage for this study since the study assumes that growth is influenced by policy variables other than technical relationship between labour and capital. Interestingly, what had become the Barro model was earlier extended [69] into two-sector production model and applied by Chen and Lee.

Ram's extension of the model has the property of flexibility to accommodate policy variables in the growth analysis of developing countries. Therefore, our model assumes that the output $(Y)$ is produced by two sectors of the economy: the government sector $(G)$ and the nongovernment sector $(N)$. We assumed that the output in the government sector (government spending) has an externality effect on output in the non-government sector - this is captured in the model as resource allocation policy of the government (R); and in addition, we also assumed that the output from each sector depends only on labour $(L)$ and capital $(K)$ inputs, then the production function for both sectors could be explained as follows:

$$
\begin{gathered}
N=n\left(L_{n}, K_{n}, \mathrm{Rg}\right) \\
G=g\left(L_{g}, K_{g}\right) \\
Y=N+G \\
L=L_{n}+L_{g} \\
K=K_{n}+K_{g}
\end{gathered}
$$

where equations 4 and 5 represent the total inputs from both sectors. Therefore, total output function becomes:

$$
Y=f\left(L, K, R_{g}\right)
$$

Assuming that the government resources $(\mathrm{G})$, are allocated to the three tiers of government - federal (F), state (S) and local (L); then

$$
G=F+S+L
$$

Equations (7) provides a statement of allocation to national and subnational governments; and if $\mathrm{X}$ denotes subnational government, therefore

$$
X=S+L
$$

Equation (8) represent fiscal decentralization, but is subsumed in (7), while (7) is imbedded in (6) respectively. Equation (6) becomes our baseline equation, which the $R_{g}$ component will be unbundled subsequently. Levine and Renelt (1992); Woller and Phillips (1998) and RodriquezPose and Krøijer (2009) corroborated this approach.

\section{Model Specification and Estimation Technique}

Given the factor input components of equation (6), we remodeled equation (6) as a Cobb-Douglas production 
function thus:

$$
Y=f\left(L^{\delta_{1}} K^{\delta_{2}} A\right)
$$

Where $\mathrm{Y}$ is the Real GDP growth rate; $\mathrm{L}$ is labour; $\mathrm{K}$ is capital - which is split into human and physical capital and $\mathrm{A}$ is the total factor productivity (TFP), which is regarded as efficiency parameter. The model assumes implicitly that exogenous variables are instrumental to the establishment of the behavior of the TFP component of the model. The TFP is therefore structured as:

$$
\begin{gathered}
A=f\left(R_{g}, \operatorname{In} F, \rho\right) \\
R_{g}=f(M, D)
\end{gathered}
$$

Where $M$ and $D$ are total government revenue redistributed to tiers of government and shares of total

$$
\ln Y_{t}=\delta_{0}+\delta_{1} \ln L_{t}+\delta_{2} \ln K_{t}{ }^{h}+\delta_{3} \ln K_{t}{ }^{P}+\delta_{4} \ln M_{t}{ }^{F}+\delta_{5} \ln D_{t}{ }^{F}+\delta_{6} \operatorname{In} F_{t}+\rho+\xi_{t}
$$

Where $\delta_{0}$ is the constant parameter, $\xi_{t}$ represents the stochastic error term and rest of the variables are as were earlier defined. The $\delta_{i}$ are elasticities of the above defined variables and a priori signs are expected to be positive but indeterminate in the case of inflation. Equation 13 represents

$$
\ln Y_{t}=\delta_{0}+\delta_{1} \ln L_{t}+\delta_{2} \ln K_{t}{ }^{h}+\delta_{3} \ln K_{t}{ }^{P}+\delta_{4} \ln M_{t}{ }^{S}+\delta_{5} \ln D_{t}{ }^{S}+\delta_{6} \operatorname{In} F_{t}+\rho+\sigma_{t}
$$

Where superscripts in $\ln M_{t}{ }^{S}$ and $\delta_{5} \ln D_{t}{ }^{S}$ represents the states' contributions of the variables as described earlier.

$$
\ln Y_{t}=\delta_{0}+\delta_{1} \ln L_{t}+\delta_{2} \ln K_{t}{ }^{h}+\delta_{3} \ln K_{t}{ }^{P}+\delta_{4} \ln M_{t}{ }^{L}+\delta_{5} \ln D_{t}{ }^{L}+\delta_{6} \operatorname{In} F_{t}+\rho+\mu_{t}
$$

Where superscripts in $\ln M_{t}{ }^{L}$ and $\ln D_{t}{ }^{L}$ represents the local governments' contributions of the variables as earlier described.

The time series properties of all the variables in the model, using Augmented Dickey-Fuller (ADF) and PhillipPerron unit root tests were examined. Also, Johansen Cointegration test technique was adopted to ascertain

$$
\left[\delta_{n} R_{t}=\sigma_{1}+\sum_{i=2}^{r} \sigma_{i} \delta_{n} z_{t}-\left(\lambda E C M_{t-i}+V_{6 t}\right)\right]
$$

Where $-\lambda E C M$ is the error correction mechanism, $-\lambda$ is the magnitude of error corrected each period specified in it's a priori form, so as to restore $\delta_{n} \ln Y_{t}$ to equilibrium.

\section{Presentation of Results and Analysis of Findings}

\subsection{Data Diagnostics}

Table 1 presents the summary statistics of the data. The variables of interest have very robust mean. For example, GDPGR has the mean of about 3.410 with its distribution within the minimum and maximum limits of 33.736 and 13.128 respectively. The standard deviation stood within range of about 7.421, with skewness of 1.290 and kurtosis of whether variables are cointegrated, while Error Correction Model (ECM) was adopted to correct for the speed of adjustment of the dependent variable to short-run dynamics of the other variables, ceteris paribus. Thus, the ECM is stated thus: about 9.176 and J-B statistics of 70.941 , significant at $1 \%$ level. These statistics show the level of stability of the variable and its distribution over the time trend considered in this work. On the other hand, the correlation matrix presents a mix result, though not out of place. Apart from the inflation, whose negative correlation with economic growth may have been expected, the major decentralisation measures in the models reflected negative interaction with economic growth. FGIRR, SGIRR, FGTEXP and SGTEXP were all negatively correlated with GDPGR, except LGIRR and LGTEXP that reflected a positive correlation. As a preliminary finding, these outcomes seemingly support a strand of existing argument in the literature that decentralization may not directly result in economic growth, ceteris paribus. 
Table 1. Summary Statistics.

\begin{tabular}{|c|c|c|c|c|c|c|c|c|c|c|c|c|}
\hline & GDPGR & FGRR & SGIR & LGIR & FGTEXP & SGTEXP & LGTEXP & INF & POPGR & OPN & PHCAP & HМCAP \\
\hline Mean & 3.410601 & 1322.625 & 219.9134 & 18.54987 & 1838.962 & 1291.177 & 750.5945 & 20.04789 & 2.587879 & 1474.751 & 5.780912 & 146.9578 \\
\hline Median & 3.614657 & 629.9337 & 35.94875 & 22.76090 & 824.3705 & 263.7833 & 626.9079 & 13.80000 & 2.586550 & 278.9682 & 2.275715 & 62.32500 \\
\hline Maximum & 33.73578 & 4185.644 & 801.2875 & 38.21991 & 7813.741 & 4459.601 & 1806.913 & 76.76000 & 2.857502 & 5834.927 & 101.1660 & 582.9100 \\
\hline Minimum & -13.12788 & 5.819100 & 0.038000 & 1.035600 & 9.636500 & 5.774700 & 18.96710 & 0.220000 & 2.488183 & -2230.910 & -35.99681 & 0.240000 \\
\hline Std. Dev. & 7.421188 & 1475.928 & 295.6896 & 12.63894 & 2239.536 & 1577.280 & 659.8365 & 18.21434 & 0.080651 & 2130.609 & 27.12659 & 197.7079 \\
\hline Skewness & 1.290466 & 0.690157 & 0.995875 & -0.130526 & 1.060739 & 0.768271 & 0.243521 & 1.636409 & 0.901244 & 0.746404 & 1.283999 & 1.317488 \\
\hline Kurtosis & 9.176079 & 1.847000 & 2.286473 & 1.597897 & 2.874319 & 1.910640 & 1.471332 & 4.747838 & 4.324228 & 2.254505 & 5.554218 & 3.300202 \\
\hline Jarque-Bera & 70.94151 & 5.121572 & 7.087298 & 2.203545 & 7.151071 & 5.617142 & 2.788537 & 21.79659 & 7.920688 & 4.408383 & 20.77118 & 11.13593 \\
\hline Probability & 0.000000 & 0.077244 & 0.028908 & 0.332282 & 0.028000 & 0.060291 & 0.248014 & 0.000018 & 0.019057 & 0.110340 & 0.000031 & 0.003818 \\
\hline Sum & 129.6028 & 50259.74 & 8356.710 & 482.2967 & 69880.56 & 49064.72 & 19515.46 & 761.8200 & 98.33939 & 56040.56 & 219.6746 & 5584.396 \\
\hline Sum Sq. Dev. & 2037.739 & 80599413 & 3234996. & 3993.571 & $1.86 \mathrm{E}+08$ & 92049068 & 10884604 & 12275.20 & 0.240672 & $1.68 \mathrm{E}+08$ & 27226.52 & 1446271. \\
\hline Observations & 38 & 38 & 38 & 26 & 38 & 38 & 26 & 38 & 38 & 38 & 38 & 38 \\
\hline GDPGR & 1.00 & & & & & & & & & & & \\
\hline FGRR & -0.008060 & 1.000000 & & & & & & & & & & \\
\hline SGIR & -0.096407 & 0.934955 & 1.000000 & & & & & & & & & \\
\hline LGIR & 0.143131 & 0.903626 & 0.872817 & 1.000000 & & & & & & & & \\
\hline FGTEXP & -0.120875 & 0.937213 & 0.952611 & 0.891667 & 1.000000 & & & & & & & \\
\hline SGTEXP & -0.023246 & 0.991030 & 0.957237 & 0.918466 & 0.959016 & 1.000000 & & & & & & \\
\hline LGTEXP & 0.009270 & 0.989217 & 0.922560 & 0.894274 & 0.922708 & 0.989563 & 1.000000 & & & & & \\
\hline INF & -0.239666 & -0.436087 & -0.328063 & -0.439357 & -0.347545 & -0.385454 & -0.383272 & 1.000000 & & & & \\
\hline POPGR & 0.015289 & 0.938424 & 0.891356 & 0.863502 & 0.827503 & 0.933935 & 0.940407 & -0.342948 & 1.000000 & & & \\
\hline OPN & 0.221958 & 0.619414 & 0.402862 & 0.583538 & 0.499655 & 0.604497 & 0.669852 & -0.333685 & 0.552986 & 1.000000 & & \\
\hline PHCAP & -0.143290 & 0.185264 & 0.220980 & 0.322239 & 0.214475 & 0.173076 & 0.120773 & -0.150368 & 0.237438 & -0.032639 & 1.000000 & \\
\hline HMCAP & -0.040438 & 0.844486 & 0.787208 & 0.739059 & 0.721936 & 0.816242 & 0.823120 & -0.375329 & 0.890006 & 0.308176 & 0.234208 & 1.000000 \\
\hline
\end{tabular}

Computed by the author, using E-Views 10 .

On the other hand, the unit root test results are presented in Table 2. The results indicate that apart from GDPGR, OPN and PHCAP which were stationary at levels $[\mathrm{I}(0)]$ and at first difference [I(1)], and POPGR that was stationary only at levels $[\mathrm{I}(0)]$, there rest of the variables in the model were stationary at first difference $[\mathrm{I}(0)]$ only. The test statistic employed was Augmented Dickey-Fuller (ADF) and the stationarities were at $1 \%, 5 \%$ and $10 \%$ level of significance respectively, and the evaluation was based on their P-values. These informed our decision to investigate the existence or otherwise of cointegration among the variables. Table 3 reports the Johansen Cointegration test results. All the variables in the model are cointegrated. This outcome informed our rejection of the null hypothesis - of no cointegration - using the trace statistic.

The implication of this outcome is that there is the existence of long run equilibrium relationship among the variables, thereby underlining the need for a short run dynamic adjustment under the error correction framework. This is because, as it is conventional in modern econometrics literature, the existence of a long run relationship gives the impetus for assessing short run distortions embedded in the equilibrium relationship. Also, it is economics to understand that for every long run equilibrium interaction there is a short run distortion (disequilibrium). The short run error correction estimates are reported in Table 4.

\subsection{Models Estimates}

The results presented in Table 4 are from the estimation of equations 10, 11 and 12 in the light of equation 13. The model helps to highlight the distortions in the long run equilibrium interactions caused by shocks in the model as well as the time required for such disequilibrium to adjust to long run equilibrium. The results provide clues that, though there are potentials for growth in decentralizing fiscal operations, it may not readily provide direct interaction with economic growth.

Table 2. Unit Root Test Result.

\begin{tabular}{lll}
\hline Variables (some in log) & ADF Levels & ADF 1st Diff. \\
\hline GDPGR & $-5.0550^{* *}$ & $-8.9336^{*}$ \\
FGRR & -1.9528 & $-5.5522^{*}$ \\
SGIR & -1.8428 & $-7.6033^{*}$ \\
LGIR & -2.1573 & $-3.4127^{* * *}$ \\
FGTEXP & -1.3122 & $-4.8941^{* *}$ \\
SGTEXP & -1.3761 & $-4.2391^{* *}$ \\
LGTEXP & -2.1275 & $-4.2026^{* * *}$ \\
INF & -3.0271 & $-3.3545^{* * *}$ \\
POPGR & $-4.9437^{* *}$ & -2.7717 \\
OPN & -4.9348 & $-4.1765^{* * *}$ \\
PHCAP & $-5.9992^{*}$ & $-9.3874^{*}$ \\
HMCAP & -0.2766 & $-3.5065^{* * *}$ \\
LAB & -2.3800 & $-7.0807^{*}$ \\
\hline
\end{tabular}

Computed by the author, using E-Views $10 . *, * *, * * *$ represent $1 \% .5 \%$, and $10 \%$ level of significance.

Generally, the ECM term, for the three models, aligns with theoretical sign significantly, indicating the fact that the speed of adjustment is reasonably fast. The three models show the speed of adjustment to long-run to the tune of $105 \%, 93 \%$ and $103 \%$, respectively. The adjusted coefficient of determination $\left(\right.$ adj. $\left.\mathrm{R}^{2}\right)$ indicates that about $56 \%, 54 \%$ and $75 \%$ variation in the real GDP growth rate (economic growth) in Nigeria, is jointly explained by the fiscal decentralization variables and other explanatory variables in the model. This underlines the fact that the model adequately explains the fiscaldecentralisation-economic-growth relationship, given the 
interactions among those variables of interest. The F-statistic shows the overall significance of the modelled estimates, and this is indicative of a good fit. The Durbin-Watson (D-W) statistic has really stressed, to a reasonable extent, the absence of partial serial correlation in the model, the values stood at 1.87, 1.89 and 1.88. Jarque-Berra (J-B) F-statistic indicated a statistically insignificant situation, implying that the estimated residuals are normally distributed.

Table 3. Johansen Hypothesized Cointegrating Relations.

\begin{tabular}{|c|c|c|c|c|c|}
\hline Null Hypothesis & Alternative Hypothesis & Eigen Value & Trace Statistic & Critical Value & Prob.** Value \\
\hline $\mathrm{R}=0 *$ & $\mathrm{R}=1$ & 0.9456 & 295.346 & 159.529 & 0.000 \\
\hline $\mathrm{R} \leq 1^{*}$ & $\mathrm{R}=2$ & 0.8198 & 199.232 & 125.615 & 0.000 \\
\hline $\mathrm{R} \leq 2^{*}$ & $\mathrm{R}=3$ & 0.7593 & 142.684 & 95.754 & 0.000 \\
\hline $\mathrm{R} \leq 3^{*}$ & $\mathrm{R}=4$ & 0.6920 & 95.685 & 69.819 & 0.000 \\
\hline $\mathrm{R} \leq 4^{*}$ & $\mathrm{R}=5$ & 0.4763 & 56.819 & 47.856 & 0.005 \\
\hline $\mathrm{R} \leq 5^{*}$ & $\mathrm{R}=6$ & 0.4081 & 35.476 & 29.797 & 0.009 \\
\hline $\mathrm{R} \leq 6^{*}$ & $\mathrm{R}=7$ & 0.2967 & 18.173 & 15.494 & 0.019 \\
\hline $\mathrm{R} \leq 8^{*}$ & $\mathrm{R}=9$ & 0.1541 & 6.722 & 3.741 & 0.001 \\
\hline $\mathrm{R} \leq 9^{*}$ & $\mathrm{R}=10$ & 0.1451 & 5.842 & 2.624 & 0.010 \\
\hline $\mathrm{R} \leq 10^{*}$ & $\mathrm{R}=11$ & 0.4652 & 4.851 & 2.728 & 0.001 \\
\hline $\mathrm{R} \leq 11 *$ & $\mathrm{R}=12$ & 0.4343 & 3.641 & 1.481 & 0.011 \\
\hline
\end{tabular}

Trace test indicates 12 cointegrating equations $5 \%$ level of significance. * indicates rejection of the null hypothesis at $5 \%$ significant level and ** is the MacKinnonHaug-Michelis (1999) p-values.

A closer look at the estimates presented in Table 4 present facts for critical reflections. All through the models, the two sets of basic fiscal decentralisation variables reflected a mix outcome. While revenue coefficients were $0.495,1.297$ and 1.340 for central, regional and local governments respectively. None of these coefficients, though positive, were statistically significant. The implication of this is that, though revenues at different levels of decentralisation seems not to exert significant impact on the economic progress of the jurisdiction, the robustness of the coefficients and the adequate a priori signs show that revenue has the potentials of impacting positively on growth of the jurisdiction, but for some macroeconomic imbalances. These imbalances may include low internally generated revenue, non- viable tax base allocation, vertical imbalances and corruption, amid other factors.

On the other hand, expenditure coefficients reflected mixed signs and were equally statistically insignificant. They were 3.363, 1.516 and -9.717 for central, regional and local governments respectively. The theoretical expectation, primarily, is that expenditure should boost economic activity, implying positive interaction with economic growth. The mixed signs, therefore, and the statistical insignificance of the coefficients could be attributed to mismanagement of funds, misguided implementation of policy processes, fiscal deficits, high rate of discomfort index, all summarised as corruption in project execution and policy implementation process.

Table 4. Short-Run Adjustment Models Estimates.

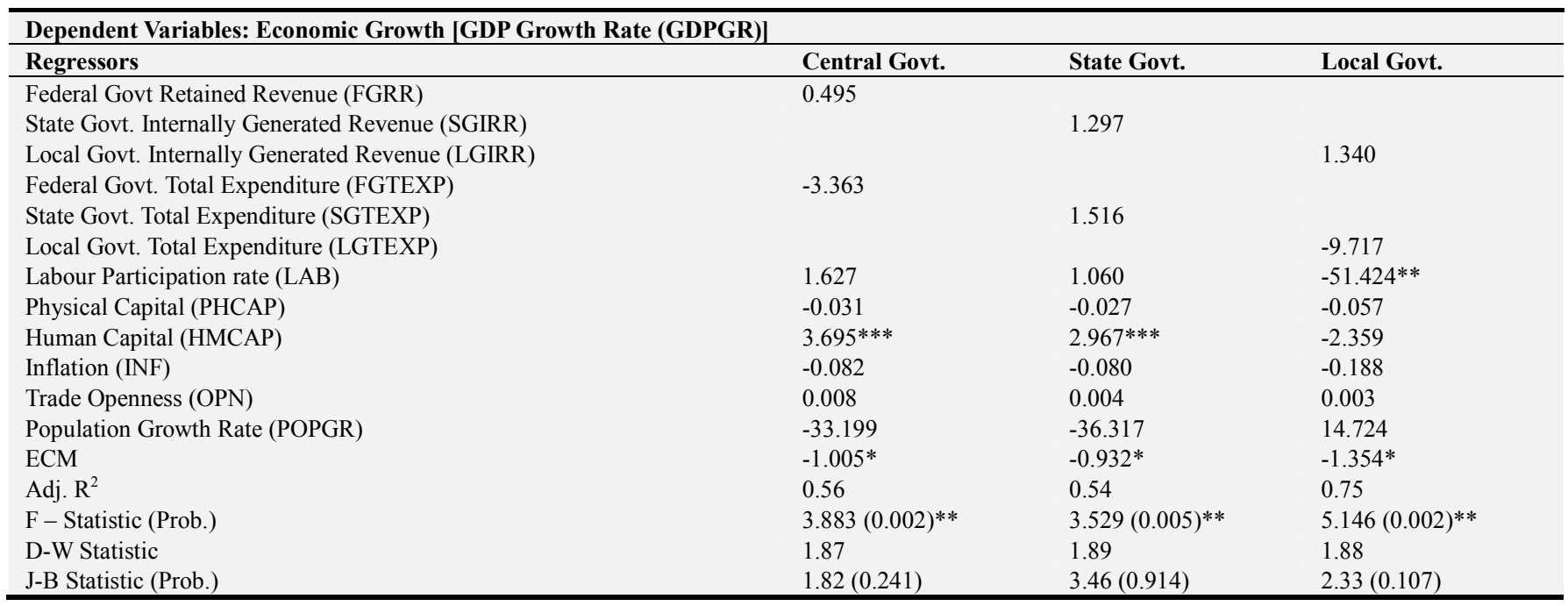

Computed by the author using E-views $10 . * *$ and $* * *$ indicate significance at $5 \%$ and $10 \%$ level respectively.

One discovery that stands out is the fact that of all other variables in the models, human capital (HMCAP) indicated a positive and significant interaction with economic growth for both central and subnational, but local jurisdictions. The coefficients were $3.695,2.967$ and -2.359 respectively. This shows that a viable and equipped human capital will certainly 
contribute to efficiency in economic activity that will lead to economic growth, ceteris paribus. The deviance in the case of local government - though may be a reflection of the attention given to human capital development at that level of governance can be attributed to the inadequacies associated with time series data, the much efforts done to clean them notwithstanding. On the other hand, physical capital has shown a negative and insignificant impact on economic growth for the three levels of fiscal decentralisation considered in this study.

The coefficients were $-0.031,-0.027$ and -0.057 , showing a $3.1 \%, 2.7 \%$ and $5.7 \%$ respectively, drop in economic progress as $1 \%$ more investment in physical capital is done within the levels of fiscal decentralisation examined in this paper. This is opposed to theoretical expectations and may be unconnected from the unwholesome practices in corporate and public investment processes. These practices could range from project abandonment, inflation of project costs, to outright embezzlement of resources meant for developmental programmes. Lopsidedness in project distribution as well as that of other expenditure spread could be another matter for consideration. This means that distributing projects based on political, ethnic or tribal sentiments, rather than economic potentials, opportunities and possibilities, could lead to undesirable outcomes, hence the need for re-engineering.

However, labour, inflation, trade openness and population growth rate reflected different direction of interactions with economic growth, with one common behaviour: they were all statistically insignificant, except labour in the case of model 3 (local government equation). The parameter estimates for labour show that $1 \%$ growth in labour input would have improved the economy of the central and subnational governments to about $1.6 \%$ and $1.0 \%$, but results in humongous drop in economic growth of about $51.4 \%$ in the case of local government. this further confirms the human capital development problem associated with local administration of the economy. It further goes on to show that the rationing of the foundational education (Universal Basic Education or primary education) system decentralized to the local control may be of a very serious defect.

Inflation follows the proper signs. It shows that a $1 \%$ rise in inflation rate will stifle growth to the tune of about $8.2 \%, 8.0 \%$ and $5.7 \%$ respectively. Theory, however, opined that inflation level within $3 \%$ is tolerable with growth. Population growth rate, on the other hand, indicated a negative, though statistically insignificant, relationship with growth except in the case of local government. This situation is understandable, since a growing population that is not well catered for becomes a "bad" to the economy. The positive, though insignificant, elasticity of population growth rate, in the case of local administration, shows that, ceteris paribus, the growing rural population becomes effective asset for agricultural activities that culminate in the improvement of the general wellbeing of the economy. Finally, openness revealed a positive impact for all three models, though statistically insignificant. It showed that if the economy at those different levels is more open by say $1 \%$, it will bring about $0.8 \%, 0.4 \%$ and $0.3 \%$ expansion of the economy relative to the levels of fiscal decentralisation.

\section{Conclusion and Policy Implications}

Though theory have not established a direct link between fiscal decentralisation and economic growth, fiscal decentralisation should be an engine for driving growth and development in a practicing economy. Nigeria has been a federal state for some decades now, but the basic agitations for an inclusive growth and development have persisted, taking different dimensions from different regions. The new call is fiscal decentralisation, that will make the people own their governance and fiscal process, both in laws and in practice. Thus, this study attempted to establish, empirically, the direct interaction between fiscal decentralisation and economic growth for Nigeria over time. A time series data spanning 37 years $(1981$ - 2018) were collected from secondary sources (CBN and WDI, etc.), and tested using relevant econometric approach, with ECM technique being chosen for its unique features which were considered relevant for this study.

The result showed that fiscal decentralisation could actually foster economic growth, but the findings indicated that, first, this growth is not as a result of direct interaction, as evidence in the insignificant relationship of the fiscal decentralisation variables with economic growth, but that it evolves over time through the transmission process of system efficiency, occasion by the decentralization in place. [89] and [45], and many other scholars, corroborated this finding. Second, viable human and physical capital/infrastructures are, amid other factors, the driving force of productive fiscal decentralisation process, thus, these have to be on ground to drive some strategic policies. This was reflected in the behaviour of the two strands of capital investment structure that is present in the models.

Third, the steady rise in inflation may inhibit the growth process, as reflected in the direction of interaction between growth and inflation in the models, and, fourth, growth, over the years, may have been inhibited by corruption, ineffective leadership, unconducive macroeconomic environment as well as other encumbrances, as is assumed to have been captured in the stochastic error term. It is therefore our suggestion that Nigeria should consciously make and implement laws that will foster effective, balanced and inclusive fiscal decentralisation as well as a stable macroeconomic environment; develop efficient fiscal and monetary policy structures that can contend inflation; build a strong human capital development strategy and make, strengthen and implement laws that will be very hostile to corruption and every other forms of sharp practices, if it must benefit from the progress that characterise a fiscally decentralized economy.

\section{References}

[1] Agarwal, A. (2018). Non-uniform Impact of Fiscal Decentralization on Economic Growth: A State Level Analysis in China. https://ssm.com/abstract-3472373. 
[2] Aigbokhan, B. E. (1999), 'Fiscal Federalism and Economic Growth in Nigeria', Proceedings of the Annual Conference of the Nigerian Economic Society, NES, 333-352.

[3] Akai, N., \& Sakata, M. (2002). Fiscal decentralization contributes to economic growth: evidence from state level cross-section data for the United States. Journal of urban economics, 52 (1), 93-108.

[4] Altunbas, Y., and J. Thornton. (2012). Fiscal Decentralization and Governance. Public Finance Review 40: 66-85.

[5] Arzaghi, M., and J. V. Henderson. (2005). Why Countries Are Fiscally Decentralizing. Journal of Public Economics 89: 1157-89.

[6] Aschauer, D. (1989). Is Public Expenditure Productive? Journal of Monetary Economics, 177-200.

[7] Bahl, R. W., \& Linn, J. F. (1992). Urban public finance in developing countries. The World Bank.

[8] Balunywa, W., S. Nangoli, G. W. Mugerwa, J. Teko, and K. G. Mayoka. (2014). An Analysis of Fiscal Decentralization as a Strategy for Improving Revenue Performance in Ugandan Local Governments. Journal of Research in International Business and Management 4: 28-36.

[9] Bardhan, P. (2002). Decentralization of governance and development. Journal of Economic perspectives, 16 (4), 185-205.

[10] Barro, R. (1990). Government Spending in a Simple Model of Endogenous Growth. Journal of Political Economy 98: 103125.

[11] Baskaran, T., \& Feld, L. P. (2013). Fiscal decentralization and economic growth in OECD countries: is there a relationship? Public Finance Review, 41 (4), 421-445.

[12] Bennett, R. J. (1990), Decentralization: Local Governments and Markets. Policy Studies Journal. Wiley Oline Library.

[13] Bird, R. M., R. D. Ebel, and C. I. Wallich, (Eds). (1995). Decentralization of the Socialist State. Washington D.C.: World Bank.

[14] Blöchliger, H. (2013). Decentralization and Economic Growth-Part 1: How Fiscal Federalism Affects Long-Term Development, OECD Working Papers on Fiscal Federalism. No. 14; Paris: OECD Publishing.

[15] Boadway, R. W. and D. Wildasin. (1984). Public Sector Economics 2nd Edition. Boston: Little Brown.

[16] Boex, J., E. Heredia-Ortíz, J. Martínez-Vázquez, A. Timofeev, and G. Yao. (2006). Fighting Poverty through Fiscal Decentralization, United States Agency for International Development (USAID) Report, Washington, DC. Available online: http://pdf.usaid.gov/pdf_docs/PNADH105.pdf

[17] Bojanic, A. N. (2018). The Impact of Fiscal Decentralization on Growth, Inflation, and Inequality in the Americas. Cepal Review 124. forthcoming.

[18] Burki, S. J., Perry, G. E., \& Dillinger, W. R. (1999). Beyond the Center: Decentralizing the State, World Bank Latin American and Caribbean Studies. Washington, DC: World Bank.

[19] Davoodi, H., \& Zou, H. F. (1998). Fiscal decentralization and economic growth: A cross-country study. Journal of Urban economics, 43 (2), 244-257.

[20] de Mello, L. R., and M. Barenstein. (2001). Fiscal
Decentralization and Governance: A Cross-Country Analysis. IMF Working Paper No. 01/71. pp. 1-31. Available online: http://ssrn.c06/0om/abstract $=879574$.

[21] Devarajan, S, V. Swaroop and H. Zou. (1996). The Composition of Public Expenditures and Economic Growth." Journal of Monetary Economics 37: 313-344.

[22] Diaz-Cayeros, A. (2006). Federalism, Fiscal Authority, and Centralization in Latin America. New York: Cambridge University Press.

[23] Eboh, E. C. (2009), "Fiscal Federalism, Subnational Governance and MDGs in Nigeria," AIAE Research paper 4. Enugu: AIAE.

[24] Ekpo, A. H and J. E. U. Ndebbio (1998), Local Government Operations in Nigeria. Research Paper 73, Nairobi: AERC.

[25] Ekpo, A. H. and Ndebbio, J. E. U. (1991), "Fiscal Operations in a Depressed Economy: Nigeria, 1960-1990". AERC Research Paper 44. Nairobi: AERC.

[26] Ekpo. A. H. and Englama, A. (2008), "Fiscal Federalism in Nigeria: Issues, Challenges and Agenda for Reform." In Collier, P., Soludo, C. C. And Pattillo, C., (Eds) Economic Policy Options for a Prosperous Nigeria. Hampshire and New York: Palgrave Macmillan. Pp. 221-243.

[27] Escobar-Lemmon, M., and A. D. Ross. (2014). Does Decentralization Improve Perceptions of Accountability? Attitudinal Evidence from Colombia. American Journal of Political Science 58: 175-88.

[28] Faguet, J-P. (2004). Does Decentralization Increase Government Responsiveness to Local Needs? Evidence from Bolivia. Journal of Public Economics 88: 867-93.

[29] Fisman, R., and R. Gatti. (2002). Decentralization and Corruption: Evidence across Countries. Journal of Public Economics 83: 325-45.

[30] Florin, O. (2015). Fiscal federalism and Fiscal Decentralization in an Enlarged European Union. Alexendra Ioan Cuza University of Iasi.

[31] Francis, P, and R. James. (2003). Balancing Rural Poverty Reduction and Citizen Participation: The Contradictions of Uganda's Decentralization Program. World Development 31: 325-37.

[32] Fukasaku, K., \& De Mello Jr, L. R. (Eds.). (1999). Fiscal decentralization in emerging economies: governance issues. OECD Publishing.

[33] Gemmell, N., \& Kneller, R. (1931). I. Sanz (2013), Fiscal Decentralization and Economic Growth in OECD Countries: Spending versus Revenue Decentralization. Economic Inquiry, 51, 1915-1931.

[34] Gemmell, N., R. Kneller, and I. Sanz. (2013). Fiscal Decentralization and Economic Growth: Spending versus Revenue Decentralization. Economic Inquiry 51: 1915-31.

[35] Goerl, C., and M. Seiferling. (2014). Income Inequality, Fiscal Decentralization and Transfer Dependency. International Monetary Fund (IMF) Working Paper 14/64, Washington, D.C. Availableonline: http://www.imf.org/external/pubs/ft/wp/2014/wp1464.

[36] Hasanli, A. (2017). Fiscal Decentralization and Economic Growth: A Dilemma between Theory and Empiricism. Khazar Journal of Humanities and Social Sciences. Vol. 20 (3). DOI: 10.5782/2223-2621.2017.20.3.77. 
[37] Hiroko U, ed. (2012). Fiscal Decentralization and Development-Experiences of Three Developing Countries in Southeast Asia. London: Palgrave MacMillan UK.

[38] Iimi, A. (2005). Decentralization and economic growth revisited: an empirical note. Journal of Urban economics, 57 (3), 449-461.

[39] Illner, M. (1999). Territorial decentralization: an obstacle to democratic reform in central and eastern Europe. The transfer of power: decentralization in Central and Eastern Europe, 7-42

[40] Islam, F. (2015). The Role of Local Self-Government Institution for Deepening Democracy at the Grass-Root Level in Bangladesh. Journal of Public Administration and Policy Research 7: 29-38.

[41] Klugman, J. (1994). decentralization: A survey of literature from a human development perspective.

[42] Kyander, A. (2014). Decentralisation, Political Participation and Democracy. Master's thesis, Lund University, Lund, Sweden. Available online: https://lup.lub.lu.se/studentpapers/search/publication/4586786.

[43] Kyriacou, A. P., L. Muinelo-Gallo, and O. Roca-Sagalés. (2015). Fiscal Decentralization and Regional Disparities: The Importance of Good Governance. Papers in Regional Science 94: 89-107.

[44] Levine, R. and Renelt, D. (1992) A sensitivity analysis of cross-country growth regressions American Economic Review 82 (4): 942-963.

[45] Lozano, I. and J. M. Julio (2016). Fiscal Decentralisation and Economic Growth in Colombia: evidence from Regional-level Panel Data. CEPAL Review 110 August.

[46] Malizia, R. and E. Tassa (2004). Administrative Decentralization versus Fiscal Federalism: Some Remarks Based on Italian and European Countries' Evidence. Paper presented at the Villa Mondragone International Economic Seminar on Rules, International Economy and Growth CEIS University of Rome Tor Verata 23-24 June.

[47] Martinez-Vazquez, J. and R. McNab (1997). Fiscal Decentralization, Economic Growth, and Democratic Governance. International Studies Program, the USAID Conference on Economic Growth and Democratic Governance Washington, D.C.

[48] Martinez-Vazquez, J., and McNab, R. (2001). Fiscal decentralization and economic growth. International Studies Program, Andrew Young School of Policy Studies, Working Paper \#01-1January.

[49] Martínez-Vázquez, J., and R. M. McNab. (2003). Fiscal Decentralization and Economic Growth. World Development 31: 1597-616.

[50] Martínez-Vázquez, J., and R. M. McNab. (2006). Fiscal Decentralization, Macrostability, and Growth. Hacienda Pública Española/Revista de Economía Pública 179: 25-49.

[51] Martinez-Vazquez, J., Lago-Peñas, S. and Sacchi, A. (2015) 'The impact of fiscal decentralization: a survey'. Working Papers Collection, A: Public Economic, governance and decentralization 1505. Universidad de Vigo, GENGovernance and Economics Research Network.

[52] Martinez-Vazquez, J., McLure, C. and Vaillancourt, F. (2006) 'Revenues and expenditures in an intergovernmental framework', in R. M. Bird and F. Vaillancourt (eds.) Perspectives on Fiscal
Federalism. Washington, DC: World Bank Publications.

[53] McKinnon, R. (1997). Market-preserving fiscal federalism in the American monetary union. Macroeconomic dimensions of public finance: Essays in honour of Vito Tanzi, 5, 73.

[54] McLure, C. and Martinez-Vazquez, J. (2004) The assignment of revenues and expenditures in intergovernmental fiscal relations. Washington, DC: World Bank.

[55] Michels, A. (2011). Innovations in Democratic Governance: How does Citizen Participation Contribute to a Better Democracy? International Review of Administrative Sciences 77: 275-93.

[56] Mohapatra, B. P. (2012). Local Self Governing Institutions and Fiscal Decentralization in India-Form to Function. Available online: http://ssrn.com/abstract $=2193836$.

[57] Mosteanu, T., Iacob, M., (2007) Fiscal Federalism, Theoretical and Applied Economics. vol. 11, p. 21, http://econpapers.repec.org.

[58] Neyapti, B. (2010). Fiscal Decentralization and Deficits: International Evidence. European Journal of Political Economy 26: 155-66.

[59] Oates, W. (1972). Fiscal Federalism. New York: Harcourt Brace Jovanovich. Polity IV Dataset http://www.bsos. umd. edu/cidcm/inscr/polity.

[60] Oates, W. (1993). Fiscal Decentralization and Economic Development." National Tax Journal 46, (2): 237-243.

[61] Oates, W. (2001). Fiscal competition and European Union: contrasting perspectives, Regional Science and Urban Economics, no. 31, pp. 133-45.

[62] Oates, W. (2002). Fiscal Federalism and European Union: Some Reflections, Societa Italiana di Economia Publica, http://www.unipv.it/websiep/wp/132.pdf, p. 2.

[63] Oates, W. E. (1994). Federalism and Government Finance. Modern Public Finance, 126.

[64] Onwioduokit, E. A. and G. E. Esu (2018). Fiscal Federation in Nigeria: Implication for Growth. West African Journal of Monetary and Economic Integration. Vol. 18, No. 2.

[65] Onwioduokit, E. A. and K. I. Obiora (2007). Fiscal Decentralization, Inflation and Economic Growth: Evidence from Nigeria. West African Journal of Monetary and Economic Integration. Vol. 7, No. 1.

[66] Paul S., E. J. Gómez, and G. E. Peterson, eds. (2007). Decentralization in Asia and Latin America-Toward a Comparative Interdisciplinary Perspective. Northampton: Edward Elgar Publishing.

[67] Piriou-Sall, S. (1998). Decentralization and rural development: A review of evidence. Washington, DC: Manuscript.

[68] Prud'Homme, R. (1995). The dangers of decentralization. The World Bank research observer, 10 (2), 201-220.

[69] Ram, R. (1986). Government Size and Economic Growth: A New Framework and Some Evidence from Cross-Section and Time-Series Data. American Economic Review (79): 191-203.

[70] Rodden, J. (2002). The dilemma of fiscal federalism: Grants and fiscal performance around the world. American Journal of Political Science, 670-687. 
[71] Rodden, J., G. Eskeland, and J. Litvack. (2003). Fiscal Decentralization and the Challenge of Hard Budget Constraints. Cambridge and London: MIT Press.

[72] Rodriguez-Pose, A., \& Gill, N. (2003). The global trend towards devolution and its implications. Environment and planning C: Government and Policy, 21 (3), 333-351.

[73] Rodriguez-Pose, A., \& Kraijer, A. (2009). Fiscal decentralization and economic growth in Central and Eastern Europe. Growth and Change, 40 (3), 387-417.

[74] Rodriguez-Pose, A., and Ezcurra, R. (2010). Is fiscal decentralization harmful for economic growth? Evidence from the OECD countries. Journal of Economic Geography, 11 (4), 619-643.

[75] Rodríguez-Pose, A., and R. Ezcurra. (2011). Is Fiscal Decentralization Harmful for Economic Growth? Evidence from the OECD Countries. Journal of Economic Geography 11: 619-43.

[76] Sacchi, A., and S. Salotti. (2014). The Effects of Fiscal Decentralization on Household Income Inequality: Some Empirical Evidence. Spatial Economic Analysis 9: 202-22.

[77] Samimi, A. J., S. K. Petanlar, G. K. Haddad, and M. Alizadeh. (2010). Fiscal Decentralization and Economic Growth: A Nonlinear Model for Provinces of Iran. Iran Economic Review 15: 125-33.

[78] Sepúlveda, C. F., and J. Martínez-Vázquez. (2011). The Consequences of Fiscal Decentralization on Poverty and Income Inequality. Environment and Planning C: Government and Policy 29: 321-43.

[79] Shen, Ch., Jing J., and H. Zou. (2012). Fiscal Decentralization in China: History, Impact, Challenges and Next Steps. Annals of Economics and Finance 13: 1-51.

[80] Song, Y. (2013). Rising Chinese Regional Income Inequality: The Role of Fiscal Decentralization. China Economic Review 27: 294-309.

[81] Sow, M. and I. F. Razafimahefa (2015). Fiscal Decentralization and the Efficiency of Public Service Delivery. International Monetary Fund Working Paper, WP/15/59.

[82] Szarowska, I. (2015). Impact of Fiscal decentralization on Economic Development in The European Union. Acta academica karviniensia.

[83] Thiessen, U. (2001). Fiscal Decentralization and Economic Growth in High-Income OECD Countries, Economics Working Papers 001. European Network of Economic Policy Research Institutes.

[84] Thiessen, U. (2003). Fiscal decentralization and economic growth in high-income OECD Countries. Fiscal studies, 24 (3), 237-274.

[85] Thornton, J. (2007). Fiscal Decentralization and Economic Growth Revisited. Journal of Urban Economics 61: 64-70.
[86] Tiebout, C. M. (1956). A pure theory of local expenditures. Journal of political economy, 64 (5), 416-424.

[87] Treisman, D. (2002). Decentralization and the Quality of Government. unpublished paper, Department of Political Science, UCLA.

[88] Udah, E. B. and Ndiyo, A. N. (2011), "Fiscal Decentralization and Economic Performance: The Nigerian Experience." A Paper Presented at the 2011 Annual Conference of the Nigerian Economic Society, Covenant University, Ota, 13-15 September.

[89] Udoh, E., Afangideh, U. E. A. Udeaja (2015). Fiscal Decentralization, Economic Growth and Human Resource Development in Nigeria: Autoregressive Distributed Lag (ARDL) Approach. CBN Journal of Applied Statistics Vol. 6 No. 1 (a).

[90] Weingast, B. R. (1995). The economic role of political institutions: Market-preserving federalism and economic development. Journal of Law, Economics, \& Organization, 1-31.

[91] Weingast, B. R. (2009). Second Generation Fiscal Federalism: The Implications of Fiscal Incentives. Journal of Urban Economics 65: 279-93.

[92] Weitz-Shapiro, R. (2008). The Local Connection: Local Government Performance and Satisfaction with Democracy in Argentina. Comparative Political Studies 41: 285-308.

[93] Woller, G M, and Phillips, K (1998) Fiscal decentralization and LDC economic growth: An empirical investigation. Journal of Development Studies 34 (4): 139-148. World Bank (2000) The World Development Report 1999/2000. Washington, D.C.

[94] World Bank Group (2001). Issues in Program Design, Decentralization Thematic Team. http://www.ciesin.org/decentralization/English/Issues.html.

[95] Xie, D, H. Zou, and H. Davoodi. (1999). Fiscal Decentralization and Economic Growth in the United States. Journal of Urban Economics 45: 228-39.

[96] Yifu Lin, J., and Z. Liu. (2000). Fiscal Decentralization and Economic Growth in China. Economic Development and Cultural Change 49: 1-21.

[97] Yilmaz, S. (1999). The impact of fiscal decentralization on macroeconomic performance. In Proceedings. Annual Conference on Taxation and Minutes of the Annual Meeting of the National Tax Association (Vol. 92, pp. 251-260). National Tax Association.

[98] Zakaria, S. (2013). The Impact of Fiscal Decentralization Toward Regional Inequalities in Eastern Region of Indonesia. Journal of Economics and Sustainable Development 4: 74-84.

[99] Zhang, T. and Zou, H. F. (1998). Fiscal decentralization, public spending, and economic growth in China. Journal of public economics, 67 (2), 221-240. 